\title{
BENTUK NOMINA BAHASA MELAYU JAMBI DI DESA PENINJAU KECAMATAN BATHIN II PELAYANG KABUPATEN MUARA BUNGO PROVINSI JAMBI (KAJIAN MORFOLOGI)
}

\author{
Ade Rahima ${ }^{1}$, Muhammad Juwanda ${ }^{2}$ \\ Program Studi Pendidikan Bahasa dan Sastra Indonesia, \\ Fakultas Keguruan dan Ilmu Pendidikan, Universitas Batanghari, \\ Jambi \\ ade_rahima@yahoo.com \\ juandakotajambi@gmail.com
}

\begin{abstract}
This research is aimed at describing the form of noun in Jambi Malay language in di Desa Peninjau. This research is qualitative descriptive. Descriptively, this research identifies the form of noun in Jambi Malay language in Desa Peninjau. The data of this research is verbal oor utterances in the form of noun which are taken from 6 informants who are the native of Jambi Malay language in Desa Peninjau. The data is collected by using observation and interview. The data is analyzzed by using distribution analysis data in which the language itself. Based on the analysis of the data, it can be known that the form of noun in Jambi Malay language in Desa Peninjau comprises, monomorpheme noun and polimorpheme noun which can be developed more. The monomorpeme noun is one syllable, two syllables, and three syllables. While the polimorpheme noun is three syllables and four syllables.
\end{abstract}

Keywords: Noun, Jambi Malay Language, Desa Peninjau

\footnotetext{
${ }^{1}$ Dosen Program Studi Pendidikan Bahasa dan Sastra Indonesia, Fakultas Keguruan dan Ilmu Pendidikan, Universitas Batanghari, Jambi

${ }^{2}$ Mahasiswa Program Studi Pendidikan Bahasa dan Sastra Indonesia, Fakultas Keguruan dan Ilmu Pendidikan, Universitas Batanghari, Jambi

Bentuk Nomina Bahasa Melayu Jambi di Desa Peninjau Kecamatan Bathin II Pelayang, Kabupaten Muara Bungo, Provinsi Jambi (Kajian Morfologi)
} 


\section{PENDAHULUAN}

Secara Historis masyarakat Jambi termasuk kelompok pemakai bahasa Melayu. Pada kenyataannya, bahasa Melayu dipakai untuk berkomunikasi antarsuku dan warga masyarakat secara nonformal, juga dipakai sebagai alat komunikasi resmi yang sarat dengan nilai-nilai budaya, seperti dalam upacara pertunangan, dan pernikahan. Fakta sosial menunjukkan bahwa bahasa Melayu juga dipakai di ranah formal yakni untuk menyampaikan pesan-pesan pembangunan kepada masyarakatnya (Rahima, 2002:1).

Melihat besarnya peranan bahasa Melayu untuk kemajuan pembangunan dan pengembangan daerah di provinsi Jambi, maka selayaknya Bahasa Melayu Jambi (disingkat BMJ) ini terus dibina dan dilestarikan. Salah satu cara pembinaan dan pelestarian bahasa tersebut adalah dengan mengadakan berbagai penelitian. Khususnya tentang pemakain bahasa Melayu di daerahdaerah di privinsi Jambi.

Salah satu bahasa Melayu yang digunakan oleh masyarakat di Desa Peninjau untuk berkomunikasi ialah bahasa Melayu Jambi. Bahasa yang dimaksud tersebut ialah bahasa daerah yang digunakan oleh sebagian masyarakat di Provinsi Jambi. Salah satu bahasa Melayu yang digunakan oleh penduduk di Desa Peninjau Kecamatan Bathin II Pelayang, Kabupaten Muara Bungo Provinsi Jambi adalah bahasa Melayu Jambi. Bahasa Melayu Jambi bermanfaat juga bagi ilmu bahasa, untuk dijadikan referensi bagi para mahasiswa, dan sekaligus mengembangkan BMJ di Desa Peninjau Kecamatan Bathin II Pelayang Kabupaten Muara Bungo Provinsi Jambi. Penelitian ini berupaya mendeskripsikan bentuk nomina Bahasa Melayu Jambi di Desa Peninjau Kecamatan Bathin II Pelayang Kabupaten Muara Bungo Provinsi Jambi.
Penelitian tentang bentuk nomina Bahasa Melayu Jambi di Desa Peninjau Kecamatan Bathin II Pelayang, Kabupaten Muara Bungo Provinsi Jambi, penting untuk diteliti karena beberapa alasan antara lain 1) belum ada kajian ilmiah khusus tentang bentuk nomina yang digunakan masyarakat desa tersebut. 2) terdapat keunikan bentuk nomina yang digunakan masyarakat desa Peninjau jika dibandingkan dengan nomina bahasa Melayu Jambi di desa lain dari aspek suku kata pada bentuk nomina monomorfemis dan polimorfemis. 3) pentingnya pelestarian bentuk-bentuk nomina tersebut agar tidak punah dan terpengaruh dengan bahasa lain yang sudah mulai merusak keunikan bahasa daerah tersebut. Contoh bentuk-bentuk nomina yang sudah jarang digunakan saat ini antara lain: 1) kuleli yang berarti mata kaki, 2) sen yang berarti uang, 3) sugeh yang berarti sikat gigi, 4) reban ayam yang berarti kandang ayam, 5) bungin yang berarti pasir, 6) pinggan yang berarti piring dan 7) gleh yang berarti gelas.

Berdasarkan uraian di atas maka fokus penelitian ini terkait dengan bentuk-bentuk nomina monomorfemis dan polimorfemis bahasa Melayu Jambi di Desa Peninjau Kecamatan Bathin II Pelayang Kabupaten Muara Bungo Provinsi Jambi. Oleh karena itu, Penelitian ini juga berusaha menjawab beberapa pertanyaan, sebagai berikut. 1) Bagaimanakah bentuk-bentuk nomina yang tergolong monomorfemis bahasa Melayu Jambi di Desa PeninjauKecamatan Bathin II Pelayang Kabupaten Muara Bungo Provinsi Jambi? 2) Bagaimanakah bentuk-bentuk nomina yang tergolong polimorfemis bahasa Melayu Jambi di Desa PeninjauKecamatan Bathin II Pelayang Kabupaten Muara Bungo Provinsi Jambi? Tujuan penelitian ini adalah untuk 
mendeskripsikan bentuk-bentuk nomina yang tergolong monomorfemis dan polimorfemis bahasa Melayu Jambi di Desa Peninjau Kecamatan Bathin II Pelayang Kabupaten Muara Bungo Provinsi Jambi.

\section{Kajian Teori}

Bahasa adalah alat yang sistematis untuk menyampaikan gagasan dan perasaan. Sebagai alat komunikasi bahasa merupakan seperangkat lambang bunyi yang bersifat konvensional, atbitrer, mempunyai makna, dan dihasilkan oleh alat ucap manusia. (Rahima, 2002, 12). Pendapat ini menegaskan bahwa penutur bahasa dalam mengimplementasikan fungsi bahasa sebagai alat komunikasi jelas akan memakai tanda-tanda, bunyi-bunyi, gesture yang berkaitan dengan mimik berdasarkan kesepakatan bersama, sehingga komunikasi dapat dipahami bersama. "Sebagai alat komunikasi verbal bahasa merupakan suatu lambang bunyi yang arbitrer" (Chaer, 2007:1). Berkaitan dengan kemajuan teknologi sekarang, masyarakat dapat berbicara langsung dengan orang lain meskipun orang itu berada beratus-ratus kilometer dari tempat tersebut.

Di Indonesia, perubahaan pemakaian bahasa Indonesia yang amat luas dan bermacam ragam penuturnya tidak dapat dihindarkan. Maka dari itu di Indonesia terdapat keberagaman bahasa. Hal tersebut terjadi karena masyarakat penuturnya yang menyerap bahasa dari berbagai daerah. Setiap bahasa pada dasarnya mempunyai ketetapan atau kesamaan dalam hal tata bunyi, tata bentuk, tata kata, tata kalimat, dan tata makna.

Morfologi merupakan kajian proses pembentukan kata yang memiliki arti, makna, dan fungsi. Menurut Suhardi (2013:28) "Morfologi adalah kajian dari bentuk kata”. Adapun menurut Menurut Djajasudarma (2010:35) "Morfologi adalah ilmu bahasa yang mempelajari morfem, dan morfem adalah unsur bahasa yang mempunyai makna dan ikut mendukung makna, makna pemahaman kata bidang morfologi melibatkan, unsur yang memiliki makna (morfem bebas) dan unsur yang ikut mendukung makna (morfem terikat). Rofii dan Franscy (2018:7) mengatakan bahwa in the morphology, described the process of word formation, said forming tool, class of words, meanings of words, as well as changes in the sound produced by the morphological process. Dapat disimpulkan bahwa morfologi merupakan ilmu linguistik yang mempelajari morfem dan kata yang mempunyai makna dan ikut mendukung makna.

Morfologi merupakan cabang ilmu yang mempelajari tentang seluk beluk kata. Tirtawijaya (1989: 3) menyatakan bahwa "Morfologi merupakan suatu deretan atau suatu daftar yang memuat kata-kata yang berhubungan dalam bentuk dan artinya”. Kemudian, ahli lain juga berpendapat bahwa "Morfologi adalah ilmu yang mempelajari bentuk-bentuk kata dan perubahan bentuk kata, serta makna yang muncul akibat perubahan bentuk itu Ramlan dalam (Pateda, 1988: 71). Dengan kata lain morfologi secara struktural objeknya adalah morfem pada tingkat terendah dan kata pada tingkat tertinggi. Salah satu dari bagian kelas kata tersebut ialah nomia atau kata benda.

Nomina atau yang sering disebut kata benda, dapat dilihat dari tiga segi, yakni segi semantis, segi sintaksis, dan segi bentuk. Secara semanatis nomina adalah kata yang mengacu pada manusia, binatang, benda, konsep atau pengertian (Alwi, 1998: 213). Dengan demikian kata seperti guru, kucing, meja, dan kebangsaan adalah nomina.

Salah satu bahasa daerah di Indonesia yang digunakan oleh masyarakat sebagai alat atau sarana 
komunikasi adalah bahasa Melayu Jambi. Menurut Collins (2005:1) bahasa Melayu Jambi adalah "Anggota terpenting dari kerabat bahasa yang memiliki batasan luas, diluncurkan dari peradaban Asia Timur pada sepuluh ribu tahun yang lalu”. Selanjutnya Colins, (2005:2) mengatakan bahwa "Bahasa Melayu termasuk bahasa Austronesia, berasal dari Kepulauan Riau (Sumatera) telah mengalami proses perkembangan. Mulamula bahasa Melayu hanya dipercakapkan terbatas oleh penuturnya di Riau dan sekitarnya”, karena kepulauan ini terletak dijalur perdagangan yang sangat ramai di Selat Malaka dan penduduknya sebagian.

Bahasa Melayu Jambi merupakan bahasa yang digunakan oleh masyarakat Melayu Jambi untuk berinteraksi antara satu dengan lainnya dalam kehidupan sehari-hari. Selain itu bahasa Melayu Jambi merupakan salah satu warisan budaya yang sangat berharga harus dijaga dan harus dilestarikan sebaik-baiknya. Untuk menjaga dan melestarikan bahasa itu, perlu dilakukan penelitian yang bertujuan mengenal lebih dalam dan lebih jauh bahasa itu, sebagai langkah penyelamatan dan pemeliharaannya dengan cara mencari sebanyak mungkin data, informasi, dan deskripsinya. Penelitian ini meneliti mengenai nomina dalam bahasa Melayu Jambi.

Nomina atau kata benda ialah kata-kata yang menyatakan benda, yaitu "Segala sesuatu yang ada di alam ini, baik binatang dan tumbuh-tumbuhan, maupun barang yang tidak hidup” (Madong Lubis (dalam Kridalaksana, 1986: 31)). Sama halnya pakar lain mengatakan bahwa "Kata benda atau nomina adalah kata-kata yang menyatakan benda, misalnya kata-kata hati, orang, rakit, hari, keadaan lautan, giliran, dan sebagainya”. (Tardjan Hardidjaja (dalam Kridalaksana, 1986: 14)).
Nomina sebagai salah satu kelas kata yang dapat diidentifikasi berdasarkan ciri-ciri yang membedakan dengan kelas kata lainnya. Batasan mengenai nomina telah diberikan oleh para pakar bahasa dengan dasar-dasar ciri tertentu yang mengunakan istilah yang bervariasi.

Beberapa penelitian terdahulu yang relevan dengan penelitian ini antara lain. Pertama, penelitian yang dilakukan oleh Kartika Wahyuningtyas (2015) yang berjudul, "Struktur Frasa Nomina dalam StikerVulgar”. Penelitian tersebut memiliki persamaan dengan penelitian ini, yaitu pada objek penelitiannya yang mengkaji nomina. Adapun perbedaannya yaitu penelitian tersebut membahas tentang struktur FN dalam stiker vulgar pada kajian sintaksis, sedangkan penelitian ini objeknya ialah masyarakat penutur asli bahasa tersebut, dan kajian yang dilakukan oleh penulis adalah kajian morfologi.

Kedua, penelitian yang dilakukan oleh Kamel Rudini (2016) yang berjudul, “Afiksasi Verba Bahasa Melayu Jambi di Desa Tuo Limbur Lubuk Mengkuang, Kabupaten Muara Bungo, Provinsi Jambi” penelitian tersebut memiliki persamaan dengan pnelitian ini yaitu sama-sama menganalisis Bahasa Melayu Jambi di Kabupaten Muara Bungo, adapun perbedaannya yaitu bahwa penelitian tersebut menganalisis afiksasi verba, sedangkan penelitian ini menganilisis bentuk nomina bahasa Melayu Jambi.

Ketiga, penelitian yang dilakukan oleh Jujur Siahaan mahasiswa Universitas Negeri Medan dengan berjudul "Analisis Morfologis Nomina Bahasa Jerman”. Data dalam penelitian ini diperoleh bahwa kategori nomina bahasa Jerman terdiri dari nomina pokok dan nomina turunan. Persamaan dari kedua penelitian ini ialah sama-sama 
mengkaji tentang morfologis nomina, sedangkan perbedaannya ialah pada penelitian tersebut mengkaji bahasa Jerman dan penelitian ini mengkaji tentang Melayu Jambi.

\section{METODE PENELITIAN}

Metode penelitian adalah cara yang dipilih oleh peneliti dengan mempertimbangkan bentuk, isi dan sifat serta sebagai subjek kajian. Jenis penelitian ini adalah penelitian deskriprif kualitatif. Jenis penelitian deskriptif merupakan cara yang digunakan penulis dengan memecahkan masalah dengan cara mendeskripsikan data-data berdasarkan fakta yang ada. Menurut Sudaryanto (dalam Muhammad, 2011: 192) "Penelitian deskriptif yaitu penelitian yang dilakukan semata-mata hanya dilakukan berdasarkan pada faktafakta yang ada atau fenomena yang secara empiris hidup pada penuturnya sehingga yang dihasilkan atau yang dicatat berupa varian bahasa yang biasa dikatakan sifatnya seperti potret atau paparan seperti apa adanya. Penelitian deskriptif dapat menggambarkan suatu gejala sosial yang terjadi pada saat ini. Penelitian deskriptif bertujuan untuk memecahkan suatu masalah yang ada pada saat ini.

Jenis penelitian kualitatif merupakan jenis penelitian yang dilakukan secara alamiah. Adapun Sugiyono (2013: 1) menyatakan sebagai berikut:

Jenis penelitian kualitatif adalah jenis penelitian yang digunakan untuk meneliti pada kondisi objek yang alamiah, (sebagai lawannya adalah eksperimen) dimana peneliti adalah sebagai instrumen kunci, teknik pengumpulan data dilakukan secara trianggulasi (gabungan) analisis data bersifat induktif, dan hasil penelitian kualitataif lebih menekankan makna dari pada generalisasi.

Penelitian kualitatif digunakan sebagai acuan dalam penelitian ini. Penulis memilih objek penelitian mengenai fenomena yang ada dalam masyarakat penutur. Menurut Muhammad (2010: 3) "Salah satu fenomena yang dapat menjadi objek penelitian kualitatif adalah peristiwa komunikasi atau berbahasa karena peristiwa ini melibatkan tuturan, makna semantik tutur, orang yang bertutur, maksud yang bertutur, situasu tutur, peristiwa tutur, tindak tutur, dan latar tuturan.

Analisis data dalam penelitian ini dilakukan setelah semua data diperoleh. Menurut Bogdam (dalam Sugiyono, 2013: 334)

Analisis data adalah proses mencari dan menyalin secara keseluruhan data yang diperoleh dari hasil wawancara, catatan lapangan dan dokumentasi, dengan cara mengorganisasikan data ke dalam kategori, menjabarkan ke dalam unit-unit, memilih mana yang penting dan yang akan dipelajari dan membuat kesimpulan sehinggah mudah dipahami oleh diri sendiri maupun orang lain.

Teknik analisis data yang digunakan dalam penelitian ini adalah teknik analisis data distribusional (Agih). Teknik analisis data distribusional (Agih) adalah metode analisis data yang alat penentunya unsur dari bahasa yang bersangkutan itu sendiri. Teknik ini digunakan untuk menganalisis bentuk nomina dalam bahasa Melayu Jambi di Desa Peninjau Kecamatan Bathin II Pelayang Kabupaten Muara Bungo Provinsi Jambi. Penerapan metode distribusional memerlukan teknik tertentu. Dalam penelitian ini teknik yang digunakan untuk menganalisis data ialah 
teknik distribusional (Agih). Sesuai dengan penelitian yang dilakukan yaitu jenis penelitian deskriptif kualitatif, maka data yang diperoleh dan dianalisis dengan menggunakan langkah-langkah sebagai berikut:

1. mengklarifikasi data;

2. mentabulasikan data;

Tabel 1. Tabel Teknik Analisis Data

\begin{tabular}{lll}
\hline NO & Nomina Bahasa Melayu Jambi di Desa Peninjau & \multicolumn{2}{c}{ Bentuk Nomina } \\
& & Monomorfemis \\
\hline 3. &
\end{tabular}

Sumber: (Sudaryanto dan modivikasi penulis)

3. menentukan bentuk-bentuk nomina bahasa Melayu Jambi di Desa Peninjau Kecamatan Bathin II Pelayang Kabupaten Muara Bungo Provinsi Jambi;

4. memberikan gambaran dalam bentuk deskriptif kualitatif secara keseluruhan mengenai bentuk nomina bahasa Melayu Jambi di Desa Peninjau Kecamatan Bathin II Pelayang Kabupaten Muara Bungo Provinsi Jambi;

5. mengabsahkan data, teknik pemeriksaan keabsahan data yang digunakan dalam penelitian ini adalah teknik triangulasi, triangulasi dengan sumber, triangulasi dengan metode dan pembimbing;

6. merumuskan kesimpulan.

\section{HASIL DAN PEMBAHASAN}

\section{Bentuk-bentuk Nomina Monomorfemis Bahasa Melayu Jambi di Desa Peninjau}

Berdasarkan hasil analisis data yang telah dikemukakan, maka diperoleh hasil berupa bentuk-bentuk nomina BMJ di Desa Peninjau Muara Bungo. Bentuk nomina monomorfemis BMJ di Desa Peninjau Muara Bungo sebanyak 116. Selanjutnya bentuk-bentuk nomina BMJ di Desa Peninjau dapat di kelompokkan berdasarkan jumlah suku kata pada bentuknya yang mencakup:
1. bentuk-bentuk nomina monomorfemis yang terdiri atas satu suku kata misalnya: (meh), (gleh), (sen), (bal) dan (breh) dsb;

2. bentuk-bentuk nomina monomorfemis yang terdiri dari dua suku misalnya: (un-jut), (ben-tal), (se-lup), (bu-li), dan (mi-ja) dsb;

3. bentuk-bentuk nomina monomorfemis yang terdiri dari tiga suku kata misalnya: (pa-ra-sut), (ka-ru-dung), (ta-la-kung), (ba-li-to), dan (ka-ri-to) dsb;

Berdasarkan data yang telah diperoleh dalam penelitian ini, ditemukan data monomorfemis yang terdiri dari satu suku kata, dua suku kata, dan tiga suku kata. Dari ketiga data tersebut, data yang paling dominan ditemukan adalah nomina monomorfemis yang terdiri dari tiga suku kata

\section{Bentuk-bentuk Nomina Polimorfemis Bahasa Melayu Jambi di Desa Peninjau}

Berdasarkan hasil analisis data yang telah dikemukakan, maka diperoleh hasil berupa bentuk-bentuk nomina polimorfemis BMJ di Desa Peninjau Muara Bungo, sebagai berikut:

1. bentuk-bentuk nomina polimorfemis yang terdiri dari tiga suku kata misalnya: (pa-ne-pak), (pa-nye-it) dan (lap-ka-ki) dsb; 
2. bentuk-bentuk nomina polimorfemis yang terdiri dari empat suku kata misalnya: (ran-jau-la-ngit), (kin-ce-angin), dan (be-tu-tu-lih) dsb;

3. bentuk-bentuk nomina polimorfemis yang terdiri dari lima suku kata misalnya:(pa-ngangat-a-yek), (pa-la-pik-mi-ja), dan (pa-nge-lap-be-dan) dsb.

Berdasarkan data yang telah diperoleh dalam penelitian ini, ditemukan data polimorfemis yang terdiri dari tiga suku kata, empat suku kata, dan lima suku kata. Dari ketiga data tersebut, data yang paling dominan adalah yang terdiri dari empat suku kata.

\section{Bentuk nomina BMJ di Desa Peninjau yang tergolong monomorfemis satu suku kata sebagai berikut.}

a. Nomina meh dalam bahasa Melayu Jambi Desa Peninjau termasuk bagian dari nomina monomorfemis. Nomina meh dalam BMJ Desa Peninjau yang berarti emas hanya terdiri dari satu morfem bebas, nomina meh tidak bisa lagi dibagi dari segi suku kata nya, sehingga nomina tersebut termasuk bagian dari nomina mono morfemis yang terdiri dari satu suku kata.

b. Nomina gleh dalam bahasa Melayu Jambi Desa Peninjau termasuk bagian dari nomina monomorfemis. Nomina gleh dalam BMJ Desa Peninjau berarti gelas hanya terdiri dari satu morfem bebas, sehingga nomina gleh tidak bisa lagi dibagi dari segi suku kata nya, nomina tersebut termasuk bagian dari nomina monomorfemis yang terdiri dari satu suku kata.

c. Nomina breh dalam bahasa Melayu Jambi Desa Peninjau termasuk bagian dari nomina monomorfemis. Nomina breh dalam BMJ Desa Peninjau berarti beras hanya terdiri dari satu morfem bebas, sehingga nomina breh tidak bisa lagi dibagi dari segi suku kata nya, nomina tersebut termasuk bagian dari nomina monomorfemis yang terdiri dari satu suku kata.

d. Nomina sen dalam bahasa Melayu Jambi Desa Peninjau termasuk bagian dari nomina monomorfemis. Nomina sen dalam BMJ Desa Peninjau berarti uang hanya terdiri dari satu morfem bebas, sehingga nomina sen tidak bisa lagi dibagi dari segi suku kata nya, Nomina tersebut termasuk bagian dari nomina monomorfemis yang terdiri dari satu suku kata.

e. Nomina bal dalam bahasa Melayu Jambi Desa Peninjau termasuk bagian dari nomina monomorfemis. Nomina bal dalam BMJ Desa Peninjau yang berarti bola hanya terdiri dari satu morfem bebas, sehingga nomina bal tidak bisa lagi dibagi dari segi suku kata nya. Nomina tersebut termasuk bagian dari nomina monomorfemis yang terdiri dari satu suku kata.

Bentuk nomina BMJ di Desa Peninjau yang tergolong polimorfemis tiga suku kata sebagai berikut.

a. Nomina panyeit dalam bahasa Melayu Jambi Desa Peninjau yang berarti jarum, termasuk bagian dari nomina polimorfemis karena terdiri lebih dari satu morfem. Nomina tersebut dikan hasil oleh proses morfologis yang berupa perangkaian morfem, sehingga nomina tersebut termasuk bagian dari nomina polimorfemis. Nomina panyeit ini terdiri dari tiga suku kata (pa-nyeit).

b. Nomina panepak dalam bahasa Melayu Jambi Desa Peninjau berarti raket, termasuk bagian dari nomina polimorfemis karena terdiri lebih dari satu morfem. Nomina tersebut dikan hasil oleh proses morfologis yang berupa perangkaian morfem, sehingga nomina tersebut termasuk bagian dari nomina polimorfemis. Nomina 
panepak ini terdiri dari tiga suku kata (pa-ne-pak).

c. Nomina lapkaki dalam bahasa Melayu Jambi Desa Peninjau yang berarti keset, termasuk bagian dari nomina polimorfemis karena terdiri lebih dari satu morfem. Nomina tersebut dikan hasil oleh proses morfologis yang berupa perangkaian morfem, sehingga nomina tersebut termasuk bagian dari nomina polimorfemis. Nomina lapkaki ini terdiri dari tiga suku kata (lap-ka-ki).

\section{SIMPULAN}

Berdasarkan hasil penelitian dan pembahasan mengenai bentuk nomina dalam bahasa melayu Jambi pada masyarakat Desa Peninjau Kecamatan Bathin II Pelayang, Kabupaten Muara Bungo Provinsi Jambi, maka dapat disimpulkan bahwa terdapat 153 data Nomina BMJ di Desa Peninjau. Di antaranya data nomina monomorfemis yang dominan ialah nomina yang terdiri dari dua suku kata dan nomina polimorfemis yang dominan ialah nomina yang terdiri dari empat suku kata.

Berdasarkan uraian di atas dapat disimpulkan bahwa terdapat keunikan bentuk nomina yang digunakan oleh masyarakat Desa Peninjau Kecamatan Bathin II Pelayang, Kabupaten Muara Bungo Provinsi Jambi yaitu memiliki bentuk nomina monomorfemis dan polimorfemis yang bervariasi.

Berdasarkan hasil penelitian ini dapat disarankan kepada para peneliti kebahasaan agar dapat melanjutnkan penelitian ini, mengingat data yang digunakan merupakan data murni yang tidak diubah penulisannya, baik ejaan maupun pola kalimatnya sehingga dapat dijadikan sumber data yang mungkin dapat diteliti dari aspek lainnya.
DAFTAR PUSTAKA

Alwi, Hasan. (1998). Tata Bahasa Baku Bahasa Indonesia. Jakarta: Balai Pustaka.

Chaer, Abdul. (2007). Linguistik Umum. Jakarta: Rineka Cipta.

Colins, James T. (2005). Bahasa Melayu, Bahasa Dunia:Sejarah Singkat. Jakarta: Yayasan Pustaka Obor Indonesia.

Djajasudarma, Fatimah. (2010). Metode Linguistik. Bandung: Refika Aditama.

Kridalaksana, H. (1986). Kelas Kata dalam Bahasa Indonesia. Jakarta: PT. Gramedia.

Muhammad. (2011). Metode Penelitian Bahasa. Yogyakarta: Ar-Ruzz Media.

Pateda, M. (1988). Linguistik (Sebuah Pengantar). Bandung: Angkasa.

Rahima, A. (2002). Sistem sapaan bahasa Melayu Jambi: laporan penelitian. Fakultas Keguruan dan Ilmu Pendidikan, Universitas Batanghari.

Rofii, Afif. dan Franscy. (2018). The Development of Contextual-Based Texbook on Morphological Process in Faculty of Teachers Training and Education Batanghari University Jambi. The Asian ESP Journal. Volume 14 Issue 2 Juli 2018. ISSN 22060979. https://www.asian-espjournal.com/2018/volume-14issue-2-july-2018/

Sugiyono. (2013). Metode Penelitian Kuantitatif Kualitatif dan $R \& D$. Bandung: Alfabeta.

Suhardi. (2013). Pengantar Linguistik Umum. Yogyakarta: Ar-Ruzz Media.

Tirtawijaya, Totong. (1989). Morfologi Bahasa Indonesia. Surabaya: Institut Keguruan dan Ilmu Pendidikan Surabaya. 